Kaganga : Jurnal Pendidikan Sejarah dan Riset Sosial Humaniora

Volume 2, Nomor 1, Juni 2019

e-ISSN : 2598-4934

$p-I S S N: 2621-119 X$

DOI : https://doi.org/10.31539/kaganga.v2i1.755

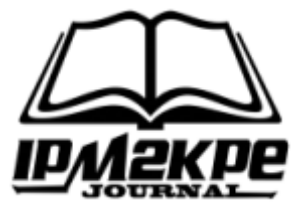

\title{
PENGARUH METODE PEMBELAJARAN POHON KELUARGA DALAM MENINGKATKAN HASIL BELAJAR PADA MATA PELAJARAN SEJARAH
}

\author{
Destel Meri \\ STKIP Yayasan Abdi Pendidikan Payakumbuh \\ destelmeri05@gmail.com
}

\begin{abstract}
ABSTRAK
Penelitian ini bertujuan untuk mengetahui pengaruh penerapan metode Pohon Keluarga terhadap hasil belajar siswa dalam pembelajaran Sejarah dikelas X SMAN 1 Kecamatan Payakumbuh. Jenis penelitian ini adalah penelitian quarsi eksperimental. Populasi dalam penelitian ini yaitu seluruh siswa kelas X SMAN 1 Kecamatan Payakumbuh yang terdiri dari 4 kelas dengan jumlah seluruh siswa yaitu 116 siswa. Teknik pengambilan sampel diambil dengan cara proportionate stratified random sampling. Hasil dari analisa data didapat Thitung $=5,05$ dan $T_{\text {tabel }}=1,68$ dimana $1,68<5,05>1,68$ yang berarti hipotesis diterima pada taraf kepercayaan $95 \%$. Dengan demikian dapat disimpulkan bahwa, terdapat pengaruh penerapan metode pembelajaran Pohon Keluarga terhadap hasil belajar siswa dibandingkan metode pembelajaran konvensional dalam pembelajaran sejarah di kelas X SMA N 1 Kecamatan Payakumbuh.
\end{abstract}

Kata Kunci: Metode Pohon Keluarga, Hasil Belajar

\begin{abstract}
This study aims to determine the effect of applying the Family Tree method on student learning outcomes in learning History in class X SMAN 1 Payakumbuh District. This type of research is experimental quarsi research. The population in this study were all students of class X SMAN 1 District Payakumbuh consisting of 4 classes with the total number of students, namely 116 students. The sampling technique was taken by proportionate stratified random sampling. The result from the data analysis, it was obtained Thitung $=5.05$ and $T$ table $=1.68$ where 1.68 $<5.05>1.68$ which means that the hypothesis was accepted at the $95 \%$ confidence level. Thus it can be concluded that, there is the influence of the application of the Family Tree learning method to student learning outcomes compared to conventional learning methods in history learning in class X SMA N 1 Payakumbuh District.
\end{abstract}

Keywords: Family Tree Method and Learning Outcomes 


\section{PENDAHULUAN}

Makna dan hakikat belajar diartikan sebagai proses membangun pemahaman terhadap informasi atau pengalaman. Proses membangun makna tersebutdapatdilakukan sendiri oleh siswa atau bersama orang lain. Proses itu disaring dengan persepsi, pikiran (pengetahuan awal), dan perasaan siswa. Belajar bukanlah proses menyerap pengetahuan yang sudah jadi bentukan guru. Buktinya, hasil ulangan siswa berbeda-beda pada hal mendapat pengajaran yang sama, dari guru yang sama, dan pada saat yang sama.

Pembelajaran yang bermakna akan membawa siswa pada pengalaman belajar yang mengesankan. Pengalaman siswa akan semakin berkesan apabila proses pembelajaran yang diperolehnya merupakan hasil pemahaman dan penemuannya sendiri. Dalam konteks ini siswa mengalami dan melakukannya sendiri. Proses pembelajaran yang berlangsung melibatkan siswa sepenuhnya untuk merumuskan sendiri suatu konsep. Keterlibatan guru hanya sebagai fasilitator dan moderator dalam proses pembelajaran tersebut.

Namun sistem pembelajaran duduk tenang, mendengarkan informasi dari guru sepertinya sudah membudaya sejak dulu, sehingga untuk mengadakan perubahan kearah pembelajaran yang aktif, kreatif, menyenangkan agak sulit. Guru seringkali mendapatkan kendala bagaimana memilih dan menggunakan metode dalam pembelajaran metode dan strategi yang bagaimana yang paling disukai siswa, sehingga akan tercipta pembelajaran yang aktif, inivatif, kreatif, menyenangkan gembira dan berbobot.

Dalam mata pelajaran Sejarah dihadapi berbagai kendala dalam menyampaikan materi pembelajaran, khususnya dalam memilih metode, agar pembelajaran tidak membosankan. Tidak dipungkiri bahwa pembelajaran sejarah selama ini tidak luput dari kecendrungan proses pembelajaran teacher centered. kondisi demikian tentu membuat proses pembelajaran hanya dikuasai guru. Ditambah pembelajaran sejarah merupakan mata pelajaran sarat materi sehingga siswa dituntut memiliki pemahaman yang holistic terhadap materi yang disampaikan guru. Pembelajaran yang bersifat monoton ini akan membosankan dan terus berlangsung apabila para guru hanya menggunakan metode yang konvensional saja, tidak melakukan perubahan dalam kegiatan pembelajarannya.

Berdasarkan observasi bahwa hasil belajar dan aktivitas belajar siswa SMA Negeri1 Kec. Payakumbuh khususnya kelas X IPS masih kurang dalam mengikuti pembelajaran karena metode dalam pembelajaran yang kurang diminati siswa dikarenakan, materi dalam pelajaran sejarah membosankan, guru yang selalu bercerita didepan kelas dengan menggunakan metode ceramah,terlalu banyak hafalan, sumber materi terbatas, sulit menghidupkan suasana belajar dikelas khususnya saat pelajaran sejarah, siswa hanya mendengarkan materi yang dijelaskan tanpa bisa memahami materi.

Dalam pelajaran sejarah kendala yang dihadapi guru berupa, sulit membangkitkan minat belajar siswa 
terhadap pelajaran sejarah karena pelajaran yang dianggap membosankan, alternative pemilihan metode tidak banyak karena materi dan metode yang harus disesuaikan, hanya materi tertentu yang bisa menggunakan metode seperti pembelajaran audio video pada materi pra sejarah, metode ceramah banyak digunakan untuk membuat siswa lebih memahami pelajaran sejarah, materi yang diajarkan hanya bertopik pada kejadian masa lampau.

Dari permasalahan diatas maka dilakukan observasi di SMANegeri1Kec. Payakumbuh khususnya kelas X IPS yang dalam pembelajaran kurang memuaskan, yaitu dari $100 \%$ siswa,70\% siswa belum mencapai KKM, dan hanya30\% yang mencapai KKM.

Hasil belajar diperoleh pada akhir proses pembelajaran dan berkaitan dengan kemampuan siswa dalam menyerap atau memahami suatu bahan yang telah diajarkan.

Menurut kamus besar bahasa Indonesia (2008) metode adalah cara teratur diakhiri dengan proses evaluasi hasil belajar, disisi siswa hasil belajar merupakan puncak proses belajar".

Dari beberapa pendapat tersebut dapat disimpulkan bahwa prestasi atau hasil belajar adalah tingkat keberhasilan yang diperoleh seseorang dari kegiatan belajar yang dinyatakan dalam bentuk nilai.

Dari beberapa pendapat tersebut dapat disimpulkan bahwa prestasi atau hasil belajar adalah tingkat keberhasilan yang diperoleh seseorang dari kegiatan belajar yang dinyatakan dalam bentuk nilai.

Kognitif mengacu pada hasil belajar yang berkenaan dengan pengembangan kemampuan otak dan penalaran siswa. Menurut Bloom dalam (Nana Sudjana dan rifai, 2008), domain kognitif ini memiliki enam tingkatan, yaitu ingatan, pemahaman, penerapan, analisis, sintesis, dan evaluasi.

Menurut Djamarah (2008) faktor-faktor yang mempengaruhi hasil belajar terdiri atas beberapa faktor yang meliputi, (1) faktor lingkungan, lingkungan merupakan bagian dari kehidupan anak didik, faktor lingkungan meliputi faktor alami dan faktor lingkungan budaya, (2) faktor instrumental yaitu setiap sekolah mempunyai tujuan yang akan dicapai, meliputi kurikulum, program, sarana dan fasilitas guru, (3) faktor kondisi fisiologis, kondisi fisiologis pada umumnya sangat mempengaruhi terhadap kemampuan belajar seseorang, dan (4) faktor kondisi fisiologis, faktor fisiologis sebagai faktor dari dalam tentu saja merupakan hal yang utama dalam menentukan intesitas belajar seorang anak,yang termasuk faktor psikologis meliputi minat, kecerdasan, bakat, motivasi dan kemampuan kognitif.

Menurut Purwanto (2007) faktor-faktor yang mempengaruhi hasil belajar adalah tergolong menjadi dua golongan yang meliputi, (a) faktor yang ada pada diri organisme itu sendiri yang disebut dengan faktor indidual, dan (b) faktor yang ada diluar individu yang kita sebut faktor sosial. Faktor individual antara lain: faktor kematangan atau faktor pertumbuhan, kecerdasan, latihan, motivasi, dan faktor pribadi. Sedangkan yang masuk factor sosial antara lain faktor keluarga, guru dan cara mengajarnya, alat-alat yang 
digunakan dalam mengajar, dan lingkungan. Hasil belajar memang dipengaruhi oleh banyak faktor, antara lain: kemampuan guru, keadaan peserta didik, sarana dan prasarana, dan lain-lain. Namun terlepas dari itu semua, bahwa hasil belajar merupakan tanggung jawab guru. Kegagalan peserta didik mencapai tujuan yang telah ditentukan adalah kegagalan guru.

Berdasarkan pendapat para ahli diatas dapat disimpulkan bahwa faktorfaktor yang mempengaruhi hasil belajar ada beberapa faktor yaitu: faktor dari dalam diri peserta didik seperti: minat, motivasi, kecerdasan, bakat, dan kemampuan kognitif. Faktor yang dari luar diri peserta didik seperti: lingkungan keluarga, guru, teman sebaya, dan lingkungan sekitar.

Secara umum faktor-faktor yang memengaruhi belajar wajar dibedakan atasdua kategor, yaitu faktor internal dan faktor eksternal Kedua faktor tersebut saling memengaruhi dalam proses belajar indivi duse hingga menentukan kualitas hasil belajar.

\section{METODE PENELITIAN}

Jenis penelitian ini adalah penelitian quarsi eksperimental. Populasi dalam penelitian ini yaitu seluruh siswa kelas $\mathrm{X}$ SMAN 1 Kecamatan Payakumbuh yang terdiri dari 4 kelas dengan jumlah seluruh siswa yaitu 116 siswa. Teknik pengambilan sampel diambil dengan cara proportionate stratified random sampling. Metode penelitian ekperimen diartikan sebagai metode penelitian yang digunakan untuk mencari pengaruh perlakuan tertentu terhadap yang lain dalam kondisi yang terkendali.
HASIL DAN PEMBAHASAN

\section{Kelas Eksperimen}

Pada penelitian ini yang menjadi kelas eksperimen adalah kelas X.IIS 2 terdiri dari 28 siswa diantaranya 10 laki-laki dan 18 perempuan. Sebelum dilakukan perlakuan pada kelas eksperiment ini terlebih dahulu dilihat hasil belajar siswa pada semester ganjil tahun ajaran 2017/2018.

Setelah diketahui skor hasil belajar siswa kelas X.IIS 2 pada mata pelajaran sejarah dari guru mata pelajaran yaitu ibu Neni Asnita, S.Pd adalah 76,78 dengan KKM 78. Dilihat distribusi frekuensi hasil belajar siswa kelas eksperimen sebelum diterapkan model pembelajaran pohon keluarga seperti dibawah ini:

\begin{tabular}{lll}
\multicolumn{3}{l}{ Tabel 1. Distribusi frekuensi hasil ujian } \\
semester ganjil tahun ajaran 2017/2018. \\
\hline $\begin{array}{l}\text { Kelas } \\
\text { Interval }\end{array}$ & Frekuensi & Persen (\%) \\
\hline $60-70$ & 9 & $32,15 \%$ \\
$71-80$ & 14 & $50 \%$ \\
$81-90$ & 5 & $17,85 \%$ \\
$91-100$ & 0 & 0 \\
Total & 28 & $100 \%$ \\
\hline
\end{tabular}

Dari tabel diatas, dilihat hasil belajar siswa masih banyak yang dibawah KKM, dapat dilihat kurva normal sebagai berikut:

Secara keseluruhan hasil belajar kelas eksperimen adalah rata-rata : 85,71, simpang baku: 11,23, variansi 126,13. Untuk melihat distribusi frekuensi kelas eksperimen disajikan tabel dibawah ini:

Tabel 2. Distribusi frekuensi hasil belajar siswa kelas X.IIS 2.

\begin{tabular}{lll}
\hline $\begin{array}{l}\text { Kelas } \\
\text { Interval }\end{array}$ & Frekuensi & Persen (\%) \\
\hline $52-61$ & 0 & 0 \\
$62-79$ & 6 & $21,43 \%$ \\
$80-89$ & 10 & $35,72 \%$ \\
$90-100$ & 12 & $42,85 \%$ \\
Total & 28 & $100 \%$ \\
\hline
\end{tabular}


Dari tabel diatas, dapat dilihat bahwa setelah dilakukan perlakuan terhadap kelas eksperimen dengan penerapan model pembelajaran pohon keluarga dapat disimpulkan nilai ratarata siswa sudah banyak yang diatas KKM yaitu 78.

Berdasarkan data diatas, dapat dilihat histogram dan kurva normal hasil belajar kelas eksperimen total seperti dibawah ini:

\section{Kelas Kontrol}

Secara keseluruhan hasil belajar siswa kelas X.IIS 1 yang menggunakan metode konvensional diperoleh ratarata: 81,85 , simpang baku 10,91 , dan variansi: 119,08. Untuk melihat distribusi frekuensi pada kelas kontrol ini disajikan tabel dibawah ini:

Tabel 3. Distribusi frekuensi hasil belajar

\begin{tabular}{lll} 
& \multicolumn{2}{c}{ siswa kelas X.IIS 1 } \\
\hline Kelas & Frekuensi & Persen (\%) \\
Interval & & $7,15 \%$ \\
\hline $58-67$ & 2 & $32,15 \%$ \\
$68-77$ & 9 & $39,28 \%$ \\
$78-87$ & 11 & $21,42 \%$ \\
$88-100$ & 6 & $100 \%$ \\
\hline Total & 28 & \\
\hline
\end{tabular}

Dilihat dari tabel diatas, maka hasil belajar siswa yang menggunakan metode konvensional masih banyak siswa yang nilainya masih dibawah KKM yaitu 78 .

Setelah dilakukan penelitian pada kedua kelas sampel maka diperoleh hasil belajar siswa kelas eksperimen dan kelas kontrol, seperti pada tabel dibawah ini:

Dari data pada tabel diatas terdapat perbandingan signifikan dari kelas eksperimen dengan penerapan model pembelajaran pohon keluarga dengan skor 85,71 sedangkan pada kelas kontrol yang menerapkan pembelajaran memperoleh skor 81,85. Dapat disimpulkan adanya pengaruh dari penerapan model pembelajaran pohon keluarga dibandingkan dengan pembelajaran konvensional.

Setelah dilakukan penelitian pada kedua kelas sampel maka diperoleh hasil belajar siswa kelas eksperimen dan kelas control, seperti padatabel dibawah ini:

Tabel 4. Hasil belajarsiswa kelas eksperimen dan kelas kontrol.

\begin{tabular}{|c|c|c|c|}
\hline \multirow[t]{2}{*}{ Parameter } & \multicolumn{2}{|c|}{ Kelas } & \multirow[t]{2}{*}{ Ket. } \\
\hline & Eksperimen & Kontrol & \\
\hline $\begin{array}{l}\text { Rata-rata nilai } \\
\text { tesakhir }\end{array}$ & $X_{1}=85,7$ & $X_{2}=81,85$ & $\mathrm{XI}>\mathrm{X} 2$ \\
\hline \multirow[t]{2}{*}{ Uji normalitas } & $\begin{aligned} \mathrm{LO} & =0,0079 \\
\mathrm{Lt}_{\mathrm{t}} & =0,173\end{aligned}$ & $\mathrm{LO}=, 0396$ & $\begin{array}{l}\text { Berdistrib } \\
\text { usi normal }\end{array}$ \\
\hline & & $\mathrm{Lt}_{\mathrm{t}}=0,173$ & \\
\hline Uji & \multicolumn{2}{|c|}{$\mathrm{F}_{\mathrm{h}}=1,03$} & Varians \\
\hline homogenitas & \multicolumn{2}{|c|}{$\mathrm{Ft}=1,87$} & homogen \\
\hline Uji hipotesis & \multicolumn{2}{|c|}{$\mathrm{T}_{\mathrm{h}}=5,05$} & $\mathrm{H} 1$ \\
\hline & \multicolumn{2}{|c|}{$\mathrm{Tt}=1,68$} & diterima \\
\hline
\end{tabular}

Dari data pada table diatas terdapat perbandingan signifikan dari kelas eksperimen dengan penerapan model pembelajaran pohon keluarga dengan skor 85,71 sedangkan pada kelas control yang menerapkan pembelajaran konvensional memperoleh skor 81,85. Dapat disimpulkan adanya pengaruh dari penerapan model pembelajaran pohon keluarga dibandingkan dengan pembelajaran konvensional.

\section{Analisis data}

Untuk dapat menarik kesimpulan hasil penelitian dilakukan uji-t. Syarat untuk menggunakan uji-t adalah data harus berdistribusi normal dan homogen. Terlebih dahulu dilakukan uji normalitas dan homogenitas, setelah kedua pengujian tersebut 
selesai maka bisa dilakukan uji hipotesis

\section{Uji Normalitas}

Pada uji normalitas digunakan uji liliefors seperti yang tertera pada teknik analisis data. Berdasarkan ujinormalitas kelas sampel diperoleh harga Lo dan Lt pada taraf nyata 0,05 seperti pada tabel berikut:

Tabel 5: Hasil Uji Normalitas Kelas Eksperimen

$\begin{array}{llllll}\text { Kelas } & \mathrm{N} & \alpha & \mathrm{L}_{\mathrm{O}} & \mathrm{Lt} & \begin{array}{l}\text { Kesimpu } \\ \text { lan }\end{array}\end{array}$

\begin{tabular}{llllll}
\hline Eksperimen & 28 & 0,05 & 0,0079 & 0,173 & Normal
\end{tabular}

Berdasarkan table data diatas kelas sampel memiliki $\mathrm{L}_{\mathrm{O}}<\mathrm{Lt}$ berarti kelass ampel berdistribusi Normal.

\section{Uji Homogenitas}

Untuk mengetahui kedua data apakah memiliki varians homogen atau tidak, dilakukan uji $F$. Hasil analisis homogenitas terlihat pada tabel dibawah:

Tabel 6 : Hasil Uji Homogenitas Kelas Sampel

\begin{tabular}{lllcr}
\hline Kelas & $\mathrm{N}$ & Fhitung & Ftabel & keterangan \\
\hline Eksperimen & 28 & 1,03 & 1,87 & Homogen
\end{tabular}

Berdasarkan tabel diatas kelas sampel memiliki Fhitung <Ftabel, berarti kedua kelas sampel memiliki varians homogen.

\section{Uji Hipotesis}

Setelah dilakukan uji normalitas dan homogenitas, kemudian dilakukan uji hipotesis menggunakan uji-t. Dari hasil analisis diperoleh data seperti tabel dibawah:
Tabel 7 : Ringkasan Uji Hipotesis

\begin{tabular}{cc}
\hline Kelas Eksperimen & KelasKontrol \\
\hline $\mathrm{N}_{1}=28$ & $\mathrm{~N}_{2}=28$ \\
$\mathrm{X}_{1}=85,71$ & $\mathrm{X}_{2}=81,85$ \\
$\mathrm{~S}^{2}=126,13$ & $\mathrm{~S}^{2}=119,08$ \\
Thitung $: 5,05$ & \\
T $_{\text {tabel }}: 1,68$ & \\
\hline
\end{tabular}

Kesimpulan : H1diterima karena

thitung $>$ tabel

Hasil dari uji hipotesis diatas, diperoleh thitung : 5,05 sedangkan ttabel pada taraf signifikan 0,05 adalah 1,68 berarti thitung >ttabel sehingga $\mathrm{H} 1$ diterima dan Ho ditolak.

Berdasarkan deskripsi data hasil penelitian. Kelompok siswa yang mengikuti pembelajaran dengan menggunakan metode pembelajaran pohon keluarga memiliki rata-rata skor hasil belajar sejarah lebih tinggi dibandingkan dengan kelompok siswa yang mengikuti pembelajaran dengan menerapkan metode pembelajaran konvensional. Tinjauan ini didasarkan pada rata-rata skor hasil belajar sejarah siswa. Rata-rata skor hasil belajar siswa yang menerapkan model pembelajaran pohon keluarga adalah 85,71 dan rata-rata skor hasil belajar siswa yang menerapkan model pembelajaran konvensional adalah 81,85 .

Perbedaan hasil belajar sejarah antara siswa yang mengikuti pembelajaran dengan menggunakan metode pohon keluarga dan siswa yang mengikuti pembelajaran dengan metode konvensional dikarenakan perbedaan perlakuan pada langkahlangkah pembelajaran dan penyampaian materi. Metode pembelajaran pohon keluarga lebih 
menekankan pada penguatan ingatan siswa untuk dapat mempermudah dalam pemahaman, sedangkan metode pembelajaran konvensional menekankan pada hafalan. Dengan adanya perbedaan perlakuan maka sangat berpengaruh dalam meningkatkan hasil belajar siswa.

Pembelajaran dengan menggunakan metode pohon keluarga memiliki langkah-langkah yaitu, tahap persiapan (menyiapkan media pembelajaran dan bagan berupa pohon keluarga). Pembukaan (penyampaian tujuan pembelajaran dan penyampaian materi), pelaksanaan (tanya jawab dan pemberian tugas), penutup (kesimpulan, refleksi, dan evaluasi). Dapat disimpulkan penerapan model pembelajaran pohon keluarga menjadikan siswa aktif dalam pembelajaran sehingga proses pembelajaran menjadi bermakna. Dari langkah-langkah pembelajaran pohon keluarga terdapat dua tahapan penting yaitu tahap pelaksanaan dan penutup. Tahap pelaksanaan, pada tahap ini guru dan siswa melaksanakan Tanya jawab terkait materi yang telah disampaikan dalam tahap ini pulakegiatan pembelajaran diterapkan dengan model pohon keluarga dimana siswa diminta mengurutkan silsilah dari kerajaan islam dijawa. Pada kegiatan ini melatih siswa dalam kesiapannya menerima pembelajaran. Kesiatan selanjutnya yaitu mengerjakan soal latihan yang diberikan guru, dengan adanya kegiatan dalam tim dapat terjadi pertukaran pendapat, bertukar fikiran, dan usaha siswa untuk mencapai tujuan akhir dari proses pembelajaran secara maksimal.
Dengan penerapan model pembelajaran pohon keluarga pada kelasX IIS2 dapat mendorong siswa untuk bekerjasama dalam kelompok, hal ini menumbuhkan rasa keberanian antar individu dalam menjawab pertanyaan dari guru. Dalam penerapan metode pembelajaran pohon keluarga siswa dapat bersaing dengan sehat dalam menjawab pertanyaan yang diberikan oleh guru.

Penerapan metode pembelajaran pohon keluarga dapat menumbuhkan semangat kerja siswa dalam kelompok, karena dalam penerapan metode pohon keluarga siswa berusaha mencari jawaban dari pertanyaan yang diberikan dan berkonsentrasi dalam memahami pertanyaan. Kelebihan dari metode pembelajaran pohon keluarga adalah siswa lebih bersemangat dalam mengikuti pembelajaranyang diberikan olehguru, dengan menjabarkan silsilah keluarga pada bagan, sehingga adanya kreativitas siswa dalam memberikan jawaban. Hal ini menambah pengetahuan siswa dan memudahkan siswa dalam mengingat materi yang diajarkan. Dibandingkan dengan pembelajaran konvensional yang siswanya hanya mendengarkan penjelasan guru tentang materi yang diberikan, sehingga siswa akan merasa bosan mendengarkan guru menerangkan materi, disebabkan siswa tidak diberikan rangsangan yang bisa merangsang ingatan mereka dalam memahami materi pembelajaran.

\section{SIMPULAN}

Berdasarkan hasil penelitian yang telah dilakukan pada kelas $\mathrm{X}$ di SMAN 1 Kec.Payakumbuh pada mata pelajaran sejarah materi perkembangan kehidupan kerajaan islam diindonesia 
dengan penerapan model pembelajaran pohon keluarga terdapat pengaruh positif terhadap hasil belajar siswa kelas sampel yaitu kelas X IIS2 sebagai kelas eksperimen, dan kelas $\mathrm{X}$ IIS1 sebagai kelas kontrol dengan penerapan model konvensional.

Setelah dilihat hasil belajar dari kedua kelas sampel terdapat perbandingan hasil belajar antara kelas eksperimen dengan model pembelajaran pohon keluarga lebih tinggi dibandingkan dengan kelas kontrol dengan model pembelajaran konvensional yang masih rendah.

Oleh karena itu, dapat disimpulkan bahwa penerapan model pembelajaran pohon keluarga berpengaruh positif terhadap hasil belajar siswa kelas XII S2 dalam mata pelajaran sejarah dengan materi perkembangan kerajaan hindu budha diindonesia dibandingkan dengan siswa kelas XII S1 dengan materi yang sama dengan metode konvensional.

\section{DAFTARPUSTAKA}

Djamarah., B., S. (2008). Psikologi Belajar. Jakarta: Rineka Cipta

Purwanto, N. (2007). Psikologi Pendidikan Remaja. Bandung: Rosdakarya

Sudjana, N. \& Rifai, A. (2008). Media Pengajaran. Jakarta: Sinar Baru Algensindo

Tim Redaksi KBBI PB. (2008). Kamus Besar Bahasa Indonesia (Edisi Keempat). Jakarta: Pusat Bahasa Departemen Pendidikan Nasional 